\author{
MiCHAŁ JASIŃSKI \\ Szkoła Główna Handlowa w Warszawie, Polska \\ Warsaw School of Economics, Poland
}

\title{
Turystyka i pomoc rozwojowa a poziom rozwoju społeczno-ekonomicznego w państwach Południa o niekorzystnym położeniu geograficznym oraz najsłabiej rozwiniętych
}

\section{Tourism and Development Aid and the Socio-Economic Development Level of Geographically Disadvantaged and Least Developed Countries}

Streszczenie: Przedmiotem artykułu jest zbadanie stopnia znaczenia eksportu produktu turystycznego i pomocy rozwojowej oraz poziomu rozwoju społeczno-ekonomicznego w 83 państwach (Globalnego) Południa, spośród których wyróżniono państwa o tzw. niekorzystnym położeniu geograficznym oraz najsłabiej rozwinięte. Stopień znaczenia eksportu produktu turystycznego (nasycenia gospodarki turystyką) wyznaczono w oparciu o skonstruowany na potrzeby badania wskaźnik eksportu produktu turystycznego w gospodarce (WEPTG). Stopień znaczenia pomocy rozwojowej wyliczono przy zastosowaniu (skonstruowanego na potrzeby badania) wskaźnika pomocy rozwojowej w gospodarce (WPRG). Za wyznacznik poziomu rozwoju społeczno-gospodarczego przyjęto wskaźnik rozwoju społecznego (HDI) i jego miernik cząstkowy zamożność (dochód narodowy brutto per capita). Przeprowadzone analizy wykazały, że rozwój gospodarki turystycznej i związany z nią eksport produktu turystycznego był większy i bardziej znaczący dla procesów pobudzenia rozwoju w państwach o wyższym jego poziomie. W przypadkach zaś niskiego poziomu rozwoju większe znaczenie (i wyższe wpływy) były z pomocy rozwojowej. Dalsza analiza potwierdziła, że zjawisko „monokultury turystycznej” jest charakterystyczne tylko dla podgrupy małych, rozwijających się gospodarek wyspiarskich. Natomiast „monokultura pomocowa” występuje nie tylko w części małych państw wyspiarskich, ale również w niektórych państwach z grupy o większym potencjale rozwojowym. Za zjawisko niosące ze sobą większe zagrożenie z perspektywy rozwojowej uznano drugie z nich. Wyniki badania stanowią argument w dyskusji nad oceną proeksportowej specjalizacji turystycznej, przemawiający na jej korzyść.

Abstract: The aim of the article is to analyse the significance of the tourist product export and development aid, as well as the level of socio-economic development in 83 countries of the Global South. These countries have been grouped due to geographical features that significantly inhibit socio-economic development: 1) small island developing states, and 2) land-locked developing countries. These countries have been identified for the purposes of the article as countries with geographical disadvantage. In addition, a group of the least developed countries was distinguished. The significance of the tourist product export was measured by the tourism export index (WEPTG) constructed for the needs of the study. The degree of importance of development assistance (aid) was measured by the development aid in the economy (WPRG). The level 
of socio-economic level was assessed with the use of Human Development Index (HDI) and Gross National Income (GNI) per capita. The analysis shows that economies with high WEPTG were on the highest economic development level. Further analysis assets that "tourism monoculture" is significant only in small island developing states but "aid monoculture" occurs in some small states and in countries with bigger development opportunities. The research results shows that tourism specialisation in most of the analysed countries have positive aspects.

Słowa kluczowe: Południe; pomoc rozwojowa; turystyka międzynarodowa

Keywords: development aid; international tourism; the South

Otrzymano: 11 stycznia 2019

Received: 11 January 2019

Zaakceptowano: 1 maja 2019

Accepted: 1 May 2019

\section{Sugerowana cytacja / Suggested citation:}

Jasiński, M. (2019). Turystyka i pomoc rozwojowa a poziom rozwoju społeczno-ekonomicznego w państwach Południa o niekorzystnym położeniu geograficznym oraz najsłabiej rozwiniętych. Prace Komisji Geografii Przemysłu Polskiego Towarzystwa Geograficznego, 33(3), 127-147. doi: 10.24917/20801653.333.9

\section{WSTĘP}

W literaturze przedmiotu od wielu dziesięcioleci trwa debata, której celem jest próba udzielenia jednoznacznej odpowiedzi na pytanie, czy specjalizacja turystyczna (eksport produktu turystycznego) przyczynia się do pobudzenia procesów rozwoju społeczno-ekonomicznego, czy też rozwiązaniem problemów zacofania w państwach (Globalnego) Południa jest pomoc rozwojowa (Official Development Assistance - ODA). Dylemat ten stał się pretekstem do zbadania turystyki międzynarodowej i pomocy rozwojowej w grupie 83 państw Południa, z których wyróżniono państwa o tzw. niekorzystnym położeniu geograficznym oraz najsłabiej rozwinięte.

Za cel badania postawiono sobie przede wszystkim udzielenie odpowiedzi na dwa zasadnicze pytania: czy rozwój gospodarki turystycznej i związany z nią eksport produktu turystycznego był większy i bardziej znaczący dla procesów pobudzenia rozwoju w państwach o wyższym jego poziomie, czy też w państwach o niskim poziomie rozwoju większe znaczenie (i wyższe wpływy) miała pomoc rozwojowa? I drugie pytanie czy duże państwa Południa (będące przedmiotem badania) narażone są na zjawisko monokultury turystycznej albo na monokulturę pomocową oraz które ze zjawisk wydaje się być bardziej niebezpieczne w perspektywie rozwojowej?

\section{CECHY I PODSTAWOWE PROBLEMY ROZWOJOWE PAŃSTW POŁUDNIA O NIEKORZYSTNYM POŁOŻENIU GEOGRAFICZNYM ORAZ NAJSŁABIEJ ROZWINIĘTYCH}

Państwa o niekorzystnym położeniu geograficznym zostały wyróżnione spośród państw Południa (rozwijających się) ze względu na negatywne skutki oddziaływania geograficznych barier rozwojowych ${ }^{1}$. W tej grupie wydzielono dwie podgrupy: małe

${ }^{1}$ Koncepcje z zakresu ekonomii rozwoju wyjaśniające mechanizmy „głębokiego źródła rozwoju (niedorozwoju)”, odpowiadające za sukcesy i porażki procesów rozwoju społeczno-ekonomicznego, można podzielić na trzy główne nurty. Pierwszy zwraca uwagę na czynnik geograficzny. Ma on w pełni wymiar egzogeniczny. Do głównych elementów wchodzących w jego skład należy zaliczyć m.in.: klimat, zasoby naturalne oraz położenie geograficzne (bliskość rynków zbytu, izolacja terytorialna itp.). Zgodnie z perspektywą 
rozwijające się państwa wyspiarskie (Small Island Developing States - SIDS) oraz rozwijające się państwa bez dostępu do morza (śródlądowe) (Landlocked Developing Countries - LLDCs) (UNCTAD, 1973, 2010; Dudziński, 1986, 1992; Jasiński, 2017c; Jasiński, Górska, 2018).

Geograficzne bariery rozwojowe w obu podgrupach determinują (hamują) rozwój społeczno-gospodarczy w odmienny sposób. Małe gospodarki wyspiarskie cechuje specyficzna „kruchość” czy też „wrażliwość” (vulnerability), wynikająca z małych rozmiarów, ograniczonych zasobów naturalnych, izolacji oraz klęsk żywiołowych. Determinuje to m.in. wąską specjalizację i marginalne znaczenie SIDS w handlu międzynarodowym. Państwa te nie są w stanie skorzystać z efektu skali, uzależnione są od importu, charakteryzują się niskim stopniem wykorzystania zasobów pracy, kulturową dominacją Północy, wysokimi kosztami transportu, infrastruktury i administracji oraz wysoką podatnością na działalność przestępczą (m.in. pranie brudnych pieniędzy, narkotyki i korupcję) (Dudziński, 1992; Encontre, 2004; Hein, 2004; UNCTAD, 2010; Jasiński, 2017b, 2017c, 2018b).

Podstawową konsekwencją braku dostępu do morza jest konieczność korzystania przez rozwijające się państwa śródlądowe z usług tranzytowych. Powoduje to nie tylko „uzależnienie” ekonomiczne, ale również polityczne od sąsiedzkich państw świadczących tego typu usługi. Wysokie koszty transportu powodują, że realne wpływy z eksportu w LLDCs są niższe od dochodów uzyskiwanych z eksportu (podobnych) towarów przez państwa o korzystniejszym położeniu transportowym. Zjawisko to oddziałuje negatywnie na całą gospodarkę, szczególnie że większość z nich cechuje monokultura rolno-surowcowa (Dudziński, 1992; Faye, McArthur, Sachs, Snow, 2004; UNCTAD, 2010; Jasiński, 2017c; Jasiński, Górska, 2018).

Część z państw o niekorzystnym położeniu geograficznym ma również cechy państw najsłabiej rozwiniętych (Least Developed Countries - LDCs). Do tej kategorii zaliczane są jednostki geopolityczne, w których występują z reguły wszystkie (negatywne) cechy gospodarek Południa (por. Piasecki, 2003; 2007; Czaplicka, 2007) i zachodzą tam wszystkie (lub prawie wszystkie) mechanizmy „głębokich źródeł niedorozwoju”. W wyniku tego LDCs potrzebują szczególnej uwagi (wsparcia) ze strony organizacji międzynarodowych. Są państwami najbardziej zacofanymi - najsilniej potrzebującymi pomocy zagranicznej (Dudziński, 1986, 1992; UNCTAD, 2010, 2018; Jaszkiewicz, Latoszek, 2013).

\footnotetext{
„szkoły geograficznej” czynnik ten może mieć rozstrzygające znaczenie dla szans rozwojowych danego kraju. Drugi nurt wyróżnia podejście instytucjonalne. W tym przypadku źródła porażek leżą w obszarze złych, toksycznych instytucji, nieefektywnych reguł gry ekonomicznej, które hamują (blokują) planowany postęp. Kłopot stanowić mogą źle zabezpieczone prawa własności, wysokie ryzyko w obrocie towarowym, problemy korupcji czy brak (wielu) instytucji redukujących koszt transakcyjne. Zwolennicy podejścia „instytucjonalnego" postrzegają niedorozwój raczej jako czynnik o wewnętrznym charakterze. Zgodnie z tą perspektywą nie należy go szukać poza daną gospodarką. Trzeci z nurtów postrzega jako warunek (szybkiego) rozwoju integrację z gospodarką światową. Wiąże się to z rozwojem handlu oraz możliwie pełnym otwarciem własnej gospodarki - przeprowadzeniem liberalizacji na rynkach towarowych i kapitałowych. Podstawowym argumentem przedstawicieli trzeciego punktu widzenia jest stwierdzenie, że gospodarki otwarte rozwijają się szybciej niż zamknięte (Rodrik, 2002; Rodrik, Subramanian, 2003; Garbicz, 2012).
} 


\section{WSKAŹNIKI EKSPORTU PRODUKTU TURYSTYCZNEGO I POMOCY ROZWOJOWEJ W GOSPODARCE SIDS, LLDCS ORAZ W POZOSTAŁYCH LDCS}

Zgodnie z najnowszą klasyfikacją (UNCTAD, 2018) na potrzeby analizy przyjęto 83 państwa - 28 z nich posiada cechy SIDS, w tym siedem jest klasyfikowanych jako najsłabiej rozwinięte; 32 o cechach LLDCs, z czego 17 najsłabiej rozwiniętych państw bez dostępu do morza) oraz (łącznie) 47 państw najsłabiej rozwiniętych - zob. tabele 1, 2, $3^{2}$.

Tabela 1. Wskaźniki eksportu turystycznego w gospodarce (WEPTG), pomocy rozwojowej w gospodarce (WPRG) w 2016 roku, rozwoju społecznego (HDI) oraz zamożności (dochód narodowy brutto per capita) w małych rozwijających się państwach wyspiarskich (SIDS) w 2017 roku

\begin{tabular}{|c|c|c|c|c|}
\hline Państwo & WEPTG & WPRG & HDI & $\begin{array}{c}\text { Dochód narodowy } \\
\text { brutto per capita } \\
\text { (w PPP, w tys. dol.) }\end{array}$ \\
\hline Antigua i Barbuda & 0,650323 & 0,000154 & 0,780 & 20,764 \\
\hline Bahamy & 0,627506 & 0,000000 & 0,807 & 26,681 \\
\hline Barbados & 0,370384 & 0,000000 & 0,800 & 15,843 \\
\hline Dominika & 0,430412 & 0,031073 & 0,715 & 8,344 \\
\hline Federacyjne Stany Mikronezji & 0,066543 & 0,203784 & 0,627 & 3,843 \\
\hline Fidżi & 0,294592 & 0,147550 & 0,741 & 8,324 \\
\hline Grenada & 0,567201 & 0,022586 & 0,772 & 12,864 \\
\hline Jamajka & 0,386084 & 0,031297 & 0,732 & 7,846 \\
\hline Kiribati* $^{*}$ & 0,015342 & 0,275127 & 0,612 & 3,042 \\
\hline Malediwy & 0,981593 & 0,040476 & 0,717 & 13,567 \\
\hline Mauritius & 0,319936 & 0,050773 & 0,790 & 20,189 \\
\hline Nauru & 0,000000 & 0,325694 & - & 18,573 \\
\hline Palau & 0,643411 & 0,137483 & 0,798 & 12,831 \\
\hline Republika Zielonego Przylądka & 0,186647 & 0,199899 & 0,654 & 5,983 \\
\hline Samoa & 0,152502 & 0,225503 & 0,713 & 5,909 \\
\hline Seszele & 0,490607 & 0,014484 & 0,797 & 26,077 \\
\hline St. Kitts i Nevis & 0,509510 & 0,000000 & 0,778 & 23,978 \\
\hline St. Lucia & 0,559584 & 0,031756 & 0,747 & 11,695 \\
\hline St. Vincent i Grenadyny & 0,285413 & 0,026675 & 0,723 & 10,499 \\
\hline Timor Wschodni* & 0,023604 & 0,347162 & 0,625 & 6,846 \\
\hline Trynidad i Tobago & 0,103635 & 0,000000 & 0,784 & 28,622 \\
\hline Tuvalu* & 0,056575 & 0,785868 & - & 5,888 \\
\hline Vanuatu* & 0,292081 & 0,316204 & 0,603 & 2,995 \\
\hline Wyspy Marshalla & 0,024713 & 0,071938 & 0,708 & 5,125 \\
\hline Wyspy Salomona* & 0,053067 & 0,352273 & 0,546 & 1,872 \\
\hline Wyspy Św. Tomasza i Książęca* & 0,161805 & 0,179703 & 0,589 & 2,941 \\
\hline Wyspy Tonga & 0,108397 & 0,309966 & 0,726 & 5,547 \\
\hline Związek Komorów* & 0,052331 & 0,138149 & 0,503 & 1,399 \\
\hline
\end{tabular}

* Państwa klasyfikowane jako najsłabiej rozwinięte małe państwa wyspiarskie.

Źródło: obliczenia na podstawie Bank Światowy (2018) oraz UNDP (2018)

${ }^{2}$ Klasyfikacja UNCTAD budzi liczne kontrowersje, szczególnie w przypadku SIDS (por. Encontre, 2004; Hein, 2004; Jasiński, 2017b, 2018a, 2018b). 
Tabela 2. Wskaźniki eksportu turystycznego w gospodarce (WEPTG), pomocy rozwojowej w gospodarce (WPRG), rozwoju społecznego (HDI) oraz zamożności (dochód narodowy brutto per capita) w rozwijających się państwach bez dostępu do morza (LLDCs) w 2016 roku

\begin{tabular}{|c|c|c|c|c|}
\hline Państwo & WEPTG & WPRG & HDI & $\begin{array}{l}\text { Dochód narodowy } \\
\text { brutto per capita } \\
\text { (w PPP, w tys. dol.) }\end{array}$ \\
\hline Afganistan* & 0,021170 & 0,634031 & 0,498 & 1,824 \\
\hline Armenia & 0,766259 & 0,254848 & 0,755 & 9,144 \\
\hline Azerbejdżan & 0,803254 & 0,013122 & 0,757 & 15,600 \\
\hline Bhutan* & 0,432189 & 0,141165 & 0,612 & 8,065 \\
\hline Boliwia & 0,236446 & 0,176605 & 0,693 & 6,714 \\
\hline Botswana & 0,711154 & 0,081076 & 0,717 & 15,534 \\
\hline Burkina Faso* & 0,059770 & 0,234571 & 0,423 & 1,650 \\
\hline Burundi* & 0,005592 & 0,368169 & 0,417 & 0,702 \\
\hline Czad* & 0,000000 & 0,168125 & 0,404 & 1,750 \\
\hline Etiopia* & 0,352345 & 0,365291 & 0,463 & 1,719 \\
\hline Kazachstan & 0,270105 & 0,001685 & 0,800 & 22,626 \\
\hline Kirgistan & 0,455101 & 0,252472 & 0,672 & 3,255 \\
\hline Laos* & 0,357233 & 0,152107 & 0,601 & 6,070 \\
\hline Lesotho* & 0,127366 & 0,133383 & 0,520 & 3,255 \\
\hline Macedonia & 0,235520 & 0,173596 & 0,757 & 2,505 \\
\hline Malawi* & 0,047545 & 0,386287 & 0,477 & 1,064 \\
\hline Mali* & 0,075963 & 0,268137 & 0,427 & 1,953 \\
\hline Mołdawia & 0,339303 & 0,237152 & 0,700 & 5,554 \\
\hline Mongolia & 0,279710 & 0,262263 & 0,741 & 10,103 \\
\hline Nepal* & 0,180329 & 0,228227 & 0,574 & 2,471 \\
\hline Niger* & 0,111469 & 0,144036 & 0,354 & 0,906 \\
\hline Paragwaj & 0,128201 & 0,075475 & 0,702 & 8,380 \\
\hline Republika Środkowej Afryki* & 0,226820 & 0,456632 & 0,367 & 0,663 \\
\hline Rwanda* & 0,354231 & 0,360386 & 0,524 & 1,811 \\
\hline Suazi (Eswatini) & 0,027603 & 0,248159 & 0,588 & 7,620 \\
\hline Sudan Południowy* & 0,045624 & 0,846617 & 0,388 & 0,963 \\
\hline Tadżykistan & 0,139076 & 0,119048 & 0,650 & 3,317 \\
\hline Turkmenistan & 0,000000 & 0,012229 & 0,706 & 15,594 \\
\hline Uganda* & 0,247005 & 0,242007 & 0,516 & 1,658 \\
\hline Uzbekistan & 0,000000 & 0,053270 & 0,710 & 6,470 \\
\hline Zambia* & 0,256661 & 0,202053 & 0,588 & 3,557 \\
\hline Zimbabwe & 0,087054 & 0,145745 & 0,535 & 1,683 \\
\hline
\end{tabular}

* Państwa klasyfikowane jako najsłabiej rozwinięte bez dostępu do morza.

Źródło: obliczenia własne 
Tabela 3. Wskaźniki eksportu turystycznego w gospodarce (WEPTG), pomocy rozwojowej w gospodarce (WPRG), rozwoju społecznego (HDI) oraz zamożności (dochód narodowy brutto per capita) w pozostałych państwach najsłabiej rozwiniętych (LDCs) w 2016 roku

\begin{tabular}{|c|c|c|c|c|}
\hline Państwo & WEPTG & WPRG & HDI & $\begin{array}{c}\text { Dochód narodowy } \\
\text { brutto per capita } \\
\text { (w PPP, w tys. dol.) }\end{array}$ \\
\hline Angola & 0,430197 & 0,012298 & 0,581 & 5,790 \\
\hline Bangladesz & 0,283599 & 0,270925 & 0,608 & 3,677 \\
\hline Benin & 0,207805 & 0,154182 & 0,515 & 2,061 \\
\hline Birma & 0,274813 & 0,203410 & 0,578 & 5,567 \\
\hline Dżibuti & 0,334724 & 0,373936 & 0,476 & 3,392 \\
\hline Erytrea & 0,000000 & 0,089912 & 0,440 & 1,750 \\
\hline Gambia & 0,717158 & 0,157438 & 0,460 & 1,516 \\
\hline Gwinea & 0,024045 & 0,169177 & 0,459 & 2,067 \\
\hline Gwinea-Bissau & 0,453449 & 0,329267 & 0,455 & 1,552 \\
\hline Haiti & 0,783403 & 0,369815 & 0,498 & 1,665 \\
\hline Jemen & 0,061959 & 0,352315 & 0,452 & 1,239 \\
\hline Kambodża & 0,685483 & 0,159362 & 0,582 & 3,413 \\
\hline Kongo (Rep. Demokratyczna) & 0,501445 & 0,157052 & 0,457 & 0,796 \\
\hline Liberia & 0,670747 & 0,799745 & 0,435 & 0,667 \\
\hline Madagaskar & 0,334796 & 0,149946 & 0,519 & 1,358 \\
\hline Mauretania & 0,211764 & 0,169130 & 0,520 & 3,592 \\
\hline Mozambik & 0,315922 & 0,369253 & 0,437 & 1,093 \\
\hline Senegal & 0,291389 & 0,177622 & 0,505 & 2,384 \\
\hline Sierra Leone & 0,096891 & 0,420415 & 0,419 & 1,240 \\
\hline Somalia & 0,000000 & 0,404939 & - & - \\
\hline Sudan & 0,094938 & 0,096466 & 0,502 & 4,119 \\
\hline Tanzania & 0,456833 & 0,333319 & 0,538 & 2,655 \\
\hline Togo & 0,127164 & 0,064944 & 0,503 & 1,453 \\
\hline
\end{tabular}

Źródło: obliczenia własne

W celu pełniejszego wykazania ekonomicznego znaczenia turystycznej specjalizacji proeksportowej (eksportu produktu turystycznego) dla analizowanych 83 państw zastosowano, dla poszczególnych podgrup SIDS, LLDCs i LDCs, wskaźnik eksportu produktu turystycznego w gospodarce (WEPTG). Konstrukcja tego indeksu uwzględnia trzy ujęcia gospodarczego znaczenia zagranicznego przyjazdowego ruchu turystycznego.

Pierwszym są łączne wpływy z tego tytułu (tourism receipts), określone jako eksport produktu turystycznego, co na potrzeby dalszych rozważań zapisano jako EPT. Drugim jest odniesienie tych wpływów do całej gospodarki (produktu krajowego brutto) - co ujęto jako EPT/PKB (w odsetkach). Trzecim jest przeliczenie łącznych wpływów z eksportu produktu turystycznego na jednego (stałego) mieszkańca - co zapisano jako EPT per capita - zob. tabele 4, 6, 8 .

Uzyskane trzy wartości zestawiono przy zastosowaniu wzoru:

$$
\left(\mathrm{X}-\mathrm{X}_{\min }\right):\left(\mathrm{X}_{\max }-\mathrm{X}_{\min }\right)
$$

otrzymując wartości EPT, EPT/PKB oraz EPT per capita dla poszczególnego (X) państwa. 
Następnie uzyskane wartości podstawiono do wzoru:

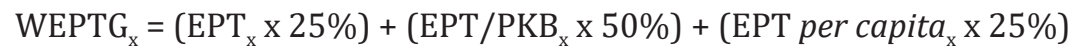

uzyskując wysokość WEPTG dla poszczególnego (X) państwa z danej podgrupy (SIDS, LLDCs, LDCs).

Tabela 4. Eksport produktu turystycznego i WEPTG w SIDS w 2016 roku

\begin{tabular}{|c|c|c|c|c|c|c|c|}
\hline \multirow{2}{*}{ Państwo } & \multicolumn{3}{|c|}{ Eksport produktu turystycznego } & EPT & $\mathrm{EPT} / \mathrm{PKB}$ & $\begin{array}{c}\text { EPT } \\
\text { per capita }\end{array}$ & \multirow{2}{*}{ WEPTG $_{\text {SIDS }}$} \\
\hline & $\begin{array}{l}\text { w mln } \\
\text { dol. }\end{array}$ & $\begin{array}{l}\text { do PKB } \\
(\%)\end{array}$ & $\begin{array}{c}\text { per capita } \\
\text { (w dol.) }\end{array}$ & \multicolumn{3}{|c|}{$\left(X-X_{\min }\right):\left(X_{\max }-X_{\min }\right)$} & \\
\hline Antigua i Barbuda & 693,0 & 47,5 & 6794,1 & 0,241969 & 0,700590 & 0,958144 & 0,650323 \\
\hline Bahamy & 2627,0 & 22,2 & 6650,6 & 0,917249 & 0,327434 & 0,937906 & 0,627506 \\
\hline Barbados & 992,0 & 21,9 & 3468,5 & 0,346369 & 0,323009 & 0,489148 & 0,370384 \\
\hline Dominika & 235,0 & 40,4 & 3175,7 & 0,082053 & 0,595870 & 0,447856 & 0,430412 \\
\hline $\begin{array}{l}\text { Federacyjne Stany } \\
\text { Mikronezji }\end{array}$ & 25,0 & 7,6 & 235,8 & 0,008729 & 0,112094 & 0,033254 & 0,066543 \\
\hline Fidżi & 1037,0 & 22,2 & 1144,6 & 0,362081 & 0,327434 & 0,161418 & 0,294592 \\
\hline Grenada & 510,0 & 48,3 & 4722,2 & 0,178073 & 0,712389 & 0,665952 & 0,567201 \\
\hline Jamajka & 2539,0 & 18,1 & 878,5 & 0,886522 & 0,266962 & 0,123891 & 0,386084 \\
\hline Kiribati & 3,4 & 1,9 & 29,3 & 0,001187 & 0,028024 & 0,004132 & 0,015342 \\
\hline Malediwy & 2864,0 & 67,8 & 6568,8 & 1,000000 & 1,000000 & 0,926370 & 0,981593 \\
\hline Mauritius & 1824,0 & 14,9 & 1441,9 & 0,636872 & 0,219764 & 0,203345 & 0,319936 \\
\hline Nauru & 0,0 & 0,0 & 0,0 & 0,000000 & 0,000000 & 0,000000 & 0,000000 \\
\hline Palau & 156,0 & 51,5 & 7090,9 & 0,054469 & 0,759587 & 1,000000 & 0,643411 \\
\hline $\begin{array}{l}\text { Republika Zielonego } \\
\text { Przylądka }\end{array}$ & 39,3 & 24,5 & 72,0 & 0,013722 & 0,361357 & 0,010154 & 0,186647 \\
\hline Samoa & 126,4 & 16,1 & 644,9 & 0,044134 & 0,237463 & 0,090948 & 0,152502 \\
\hline Seszele & 505,0 & 35,4 & 5260,4 & 0,176327 & 0,522124 & 0,741852 & 0,490607 \\
\hline St. Kitts i Nevis & 331,0 & 36,4 & 6018,2 & 0,115573 & 0,536873 & 0,848722 & 0,509510 \\
\hline St. Lucia & 770,0 & 46,2 & 4301,7 & 0,268855 & 0,681416 & 0,606651 & 0,559584 \\
\hline $\begin{array}{l}\text { St. Vincent } \\
\text { i Grenadyny }\end{array}$ & 208,0 & 27,2 & 1890,9 & 0,072626 & 0,401180 & 0,266666 & 0,285413 \\
\hline Timor Wschodni & 58,0 & 2,3 & 44,8 & 0,020251 & 0,033923 & 0,006318 & 0,023604 \\
\hline Trynidad i Tobago & 708,0 & 3,2 & 517,2 & 0,247207 & 0,047198 & 0,072939 & 0,103635 \\
\hline Tuvalu & 2,4 & 6,6 & 218,2 & 0,000838 & 0,097345 & 0,030772 & 0,056575 \\
\hline Vanuatu & 254,0 & 32,2 & 920,3 & 0,088687 & 0,474926 & 0,129786 & 0,292081 \\
\hline Wyspy Marshalla & 5,4 & 2,8 & 101,9 & 0,001885 & 0,041298 & 0,014371 & 0,024713 \\
\hline Wyspy Salomona & 71,0 & 5,8 & 116,2 & 0,024791 & 0,085546 & 0,016387 & 0,053067 \\
\hline $\begin{array}{l}\text { Wyspy Św. Tomasza } \\
\text { i Książęca }\end{array}$ & 69,2 & 19,5 & 339,2 & 0,024162 & 0,287611 & 0,047836 & 0,161805 \\
\hline Wyspy Tonga & 48,1 & 12,0 & 445,4 & 0,016795 & 0,176991 & 0,062813 & 0,108397 \\
\hline Związek Komorów & 39,3 & 6,4 & 48,3 & 0,013722 & 0,094395 & 0,006812 & 0,052331 \\
\hline
\end{tabular}

Źródło: obliczono na podstawie Bank Światowy (2018) 
Analogiczną perspektywę zastosowano dla pełniejszego wykazania ekonomicznego znaczenia pomocy rozwojowej w analizowanych SIDS, LLDCs i LDCs. Konstrukcja indeksu pomocy rozwojowej w gospodarce (WPRG) opiera się, tak samo jak WEPTG, na trzech ujęciach gospodarczego znaczenia pomocy rozwojowej. Pierwsze to łączne wpływy z tego tytułu - zapisane symbolicznie jako PR. Drugim jest odniesienie środków pomocowych do produktu narodowego brutto danej gospodarki - co oznaczono symbolicznie jako PR/PNB (w odsetkach). Trzecim zaś przeliczenie pomocy rozwojowej na jednego mieszkańca (PR per capita) - zob. tabele 5, 7, 9. Uzyskane trzy wartości (analogicznie jak w przypadku WEPTG) podstawiono do wzoru:

$$
\left(\mathrm{X}-\mathrm{X}_{\min }\right):\left(\mathrm{X}_{\max }-\mathrm{X}_{\min }\right)
$$

uzyskując wartości PR, PR/PNB oraz PR per capita dla danego (X) państwa.

Następnie uzyskane wartości podstawiono do wzoru:

$$
\mathrm{WPRG}_{\mathrm{x}}=\left(\mathrm{PR}_{\mathrm{x}} \times 25 \%\right)+\left(\mathrm{PR} / \mathrm{PNB}_{\mathrm{x}} \times 50 \%\right)+(\mathrm{PR} \text { per capita } \mathrm{x} \text { × 25\%) }
$$

uzyskując wysokość WPRG dla poszczególnego (X) państwa z danej podgrupy (SIDS, LLDCs, LDCs).

\begin{tabular}{|c|c|c|c|c|c|c|c|}
\hline \multirow{2}{*}{ Państwo } & \multicolumn{3}{|c|}{ Pomoc rozwojowa } & PR & $\mathrm{PR} / \mathrm{PNB}$ & $\begin{array}{c}\mathrm{PR} \\
\text { per capita }\end{array}$ & \multirow{2}{*}{$\mathrm{WPRG}_{\text {SIDS }}$} \\
\hline & $\begin{array}{l}\text { w mln } \\
\text { dol. }\end{array}$ & $\begin{array}{c}\text { do PNB } \\
(\%)\end{array}$ & $\begin{array}{l}\text { per capita } \\
\text { (w dol.) }\end{array}$ & \multicolumn{3}{|c|}{$\left(X-X_{\min }\right):\left(X_{\max }-X_{\min }\right)$} & \\
\hline Antigua i Barbuda & 0,1 & 0,0 & 0,8 & 0,000352 & 0,000000 & 0,000264 & 0,000154 \\
\hline Bahamy & 0,0 & 0,0 & 0,0 & 0,000000 & 0,000000 & 0,000000 & 0,000000 \\
\hline Barbados & 0,0 & 0,0 & 0,0 & 0,000000 & 0,000000 & 0,000000 & 0,000000 \\
\hline Dominika & 8,6 & 1,5 & 115,6 & 0,036771 & 0,024712 & 0,038099 & 0,031073 \\
\hline $\begin{array}{l}\text { Federacyjne Stany } \\
\text { Mikronezji }\end{array}$ & 51,3 & 13,2 & 484,2 & 0,220627 & 0,217463 & 0,159581 & 0,203784 \\
\hline Fidżi & 109,6 & 2,4 & 121,0 & 0,471242 & 0,039539 & 0,039879 & 0,147550 \\
\hline Grenada & 8,7 & 0,8 & 80,6 & 0,037420 & 0,013180 & 0,026564 & 0,022586 \\
\hline Jamajka & 26,9 & 0,2 & 9,3 & 0,115534 & 0,003295 & 0,003065 & 0,031297 \\
\hline Kiribati & 64,1 & 19,5 & 553,0 & 0,275749 & 0,321252 & 0,182256 & 0,275127 \\
\hline Malediwy & 27,5 & 0,7 & 63,0 & 0,118075 & 0,011532 & 0,020763 & 0,040476 \\
\hline Mauritius & 42,4 & 0,3 & 33,5 & 0,182168 & 0,004942 & 0,011041 & 0,050773 \\
\hline Nauru & 25,1 & 18,3 & 1795,5 & 0,108055 & 0,301483 & 0,591754 & 0,325694 \\
\hline Palau & 18,1 & 6,1 & 822,7 & 0,077801 & 0,100494 & 0,271142 & 0,137483 \\
\hline $\begin{array}{l}\text { Republika Zielonego } \\
\text { Przylądka }\end{array}$ & 114,7 & 7,2 & 210,1 & 0,493118 & 0,118616 & 0,069244 & 0,199899 \\
\hline Samoa & 88,0 & 11,4 & 449,1 & 0,378383 & 0,187809 & 0,148013 & 0,225503 \\
\hline Seszele & 5,8 & 0,4 & 60,3 & 0,024885 & 0,006590 & 0,019873 & 0,014484 \\
\hline St. Kitts i Nevis & 0,0 & 0,0 & 0,0 & 0,000000 & 0,000000 & 0,000000 & 0,000000 \\
\hline St. Lucia & 15,3 & 1,0 & 85,6 & 0,065864 & 0,016474 & 0,028212 & 0,031756 \\
\hline $\begin{array}{l}\text { St. Vincent } \\
\text { i Grenadyny }\end{array}$ & 9,2 & 1,2 & 83,7 & 0,039578 & 0,019769 & 0,027586 & 0,026675 \\
\hline
\end{tabular}

Tabela 5. Pomoc rozwojowa i WPRG w SIDS w 2016 roku 
Turystyka i pomoc rozwojowa a poziom rozwoju...

\begin{tabular}{|l|r|r|r|r|r|r|r|}
\hline Timor Wschodni & 232,6 & 10,0 & 179,5 & 1,000000 & 0,164745 & 0,059159 & 0,347162 \\
\hline Trynidad i Tobago & 0,0 & 0,0 & 0,0 & 0,000000 & 0,000000 & 0,000000 & 0,000000 \\
\hline Tuvalu & 33,4 & 60,7 & 3034,2 & 0,143471 & 1,000000 & 1,000000 & 0,785868 \\
\hline Vanuatu & 131,3 & 16,5 & 475,7 & 0,564381 & 0,271829 & 0,156779 & 0,316204 \\
\hline Wyspy Marshalla & 12,3 & 4,8 & 232,5 & 0,052972 & 0,079077 & 0,076626 & 0,071938 \\
\hline Wyspy Salomona & 185,0 & 15,6 & 302,8 & 0,795295 & 0,257002 & 0,099796 & 0,352273 \\
\hline $\begin{array}{l}\text { Wyspy Świętego } \\
\text { Tomasza i Książęca }\end{array}$ & 48,0 & 13,2 & 235,3 & 0,206339 & 0,217463 & 0,077549 & 0,179703 \\
\hline Wyspy Tonga & 80,4 & 19,7 & 744,2 & 0,345498 & 0,324547 & 0,245271 & 0,309966 \\
\hline Związek Komorów & 55,8 & 8,8 & 68,6 & 0,240036 & 0,144975 & 0,022609 & 0,138149 \\
\hline
\end{tabular}

\section{Źródło: obliczenia własne}

Tabela 6. Eksport produktu turystycznego i WEPTG w LLDCs w 2016 roku

\begin{tabular}{|c|c|c|c|c|c|c|c|}
\hline \multirow{2}{*}{ Państwo } & \multicolumn{3}{|c|}{ Eksport produktu turystycznego } & EPT & $\mathrm{EPT} / \mathrm{PKB}$ & $\begin{array}{c}\mathrm{EPT} \\
\text { per capita }\end{array}$ & \multirow{2}{*}{ WEPTG $_{\text {LLDC }}$} \\
\hline & $\begin{array}{c}\text { w mln } \\
\text { dol. }\end{array}$ & $\begin{array}{c}\text { do PKB } \\
(\%)\end{array}$ & $\begin{array}{c}\text { per capita } \\
\text { (w dol.) }\end{array}$ & \multicolumn{3}{|c|}{$\left(X-X_{\min }\right):\left(X_{\max }-X_{\min }\right)$} & \\
\hline Afganistan & 51,0 & 0,3 & 1,4 & 0,017863 & 0,031915 & 0,002985 & 0,021170 \\
\hline Armenia & 988,0 & 9,4 & 337,2 & 0,346060 & 1,000000 & 0,718977 & 0,766259 \\
\hline Azerbejdżan & 2855,0 & 7,5 & 289,5 & 1,000000 & 0,797872 & 0,617271 & 0,803254 \\
\hline Bhutan & 137,0 & 6,2 & 169,6 & 0,047986 & 0,659574 & 0,361620 & 0,432189 \\
\hline Boliwia & 801,0 & 2,4 & 72,5 & 0,280560 & 0,255319 & 0,154584 & 0,236446 \\
\hline Botswana & 1075,0 & 6,9 & 469,0 & 0,376532 & 0,734043 & 1,000000 & 0,711154 \\
\hline Burkina Faso & 103,0 & 0,9 & 5,4 & 0,036077 & 0,095745 & 0,011514 & 0,059770 \\
\hline Burundi & 1,9 & 0,1 & 0,2 & 0,000665 & 0,010638 & 0,000426 & 0,005592 \\
\hline Czad & 0,0 & 0,0 & 0,0 & 0,000000 & 0,000000 & 0,000000 & 0,000000 \\
\hline Etiopia & 2138,0 & 2,9 & 20,4 & 0,748862 & 0,308511 & 0,043497 & 0,352345 \\
\hline Kazachstan & 1716,0 & 1,3 & 95,1 & 0,601051 & 0,138298 & 0,202772 & 0,270105 \\
\hline Kirgistan & 477,0 & 7,0 & 76,9 & 0,167075 & 0,744681 & 0,163966 & 0,455101 \\
\hline Laos & 713,0 & 4,5 & 104,0 & 0,249737 & 0,478723 & 0,221748 & 0,357233 \\
\hline Lesotho & 48,0 & 2,1 & 21,5 & 0,016813 & 0,223404 & 0,045842 & 0,127366 \\
\hline Macedonia & 283,0 & 2,6 & 135,9 & 0,099124 & 0,276596 & 0,289765 & 0,235520 \\
\hline Malawi & 43,0 & 0,8 & 2,3 & 0,015061 & 0,085106 & 0,004904 & 0,047545 \\
\hline Mali & 150,0 & 1,1 & 8,1 & 0,052539 & 0,117021 & 0,017271 & 0,075963 \\
\hline Mołdawia & 331,0 & 4,9 & 93,2 & 0,115937 & 0,521277 & 0,198721 & 0,339303 \\
\hline Mongolia & 379,0 & 3,4 & 123,2 & 0,132750 & 0,361702 & 0,262687 & 0,279710 \\
\hline Nepal & 498,0 & 2,4 & 17,0 & 0,174431 & 0,255319 & 0,036247 & 0,180329 \\
\hline Niger & 140,0 & 1,8 & 6,5 & 0,049037 & 0,191489 & 0,013859 & 0,111469 \\
\hline Paragwaj & 356,0 & 1,3 & 52,3 & 0,124694 & 0,138298 & 0,111514 & 0,128201 \\
\hline $\begin{array}{l}\text { Republika } \\
\text { Środkowej Afryki }\end{array}$ & 69,8 & 4,0 & 14,9 & 0,024448 & 0,425532 & 0,031770 & 0,226820 \\
\hline Rwanda & 470,0 & 5,5 & 38,5 & 0,164623 & 0,585106 & 0,082090 & 0,354231 \\
\hline Suazi (Eswatini) & 13,2 & 0,4 & 9,7 & 0,004623 & 0,042553 & 0,020682 & 0,027603 \\
\hline Sudan Południowy & 23,5 & 0,8 & 1,9 & 0,008231 & 0,085106 & 0,004051 & 0,045624 \\
\hline Tadżykistan & 149,6 & 2,2 & 16,8 & 0,052399 & 0,234043 & 0,035821 & 0,139076 \\
\hline Turkmenistan & 0,0 & 0,0 & 0,0 & 0,000000 & 0,000000 & 0,000000 & 0,000000 \\
\hline Uganda & 768,0 & 3,2 & 17,9 & 0,269002 & 0,340426 & 0,038166 & 0,247005 \\
\hline
\end{tabular}




\begin{tabular}{|l|r|r|r|r|r|r|l|}
\hline Uzbekistan & 0,0 & 0,0 & 0,0 & 0,000000 & 0,000000 & 0,000000 & 0,000000 \\
\hline Zambia & 683,0 & 3,3 & 40,0 & 0,239229 & 0,351064 & 0,085288 & 0,256661 \\
\hline Zimbabwe & 194,0 & 1,2 & 11,7 & 0,067951 & 0,127660 & 0,024947 & 0,087054 \\
\hline
\end{tabular}

Źródło: obliczenia własne

Tabela 7. Pomoc rozwojowa i WPRG w LLDCs w 2016 roku

\begin{tabular}{|c|c|c|c|c|c|c|c|}
\hline \multirow{2}{*}{ Państwo } & \multicolumn{3}{|c|}{ Pomoc rozwojowa } & PR & $\mathrm{PR} / \mathrm{PNB}$ & $\begin{array}{c}\mathrm{PR} \\
\text { per capita }\end{array}$ & \multirow{2}{*}{$\mathrm{WPRG}_{\mathrm{LLDC}}$} \\
\hline & $\begin{array}{c}\text { w mln } \\
\text { dol. }\end{array}$ & $\begin{array}{c}\text { do PNB } \\
(\%)\end{array}$ & $\begin{array}{c}\text { per capita } \\
\text { (w dol.) }\end{array}$ & \multicolumn{3}{|c|}{$\left(X-X_{\min }\right):\left(X_{\max }-X_{\min }\right)$} & \\
\hline Afganistan & 4167,7 & 20,6 & 117,3 & 0,997679 & 0,319380 & 0,899684 & 0,634031 \\
\hline Armenia & 327,3 & 3,0 & 111,7 & 0,070920 & 0,046512 & 0,855450 & 0,254848 \\
\hline Azerbejdżan & 77,9 & 0,2 & 7,9 & 0,010742 & 0,003101 & 0,035545 & 0,013122 \\
\hline Bhutan & 52,1 & 2,5 & 64,5 & 0,004517 & 0,038760 & 0,482622 & 0,141165 \\
\hline Boliwia & 707,3 & 2,1 & 64,0 & 0,162633 & 0,032558 & 0,478673 & 0,176605 \\
\hline Botswana & 92,4 & 0,6 & 40,3 & 0,014231 & 0,009302 & 0,291469 & 0,081076 \\
\hline Burkina Faso & 1053,7 & 9,2 & 54,9 & 0,246218 & 0,142636 & 0,406793 & 0,234571 \\
\hline Burundi & 765,9 & 24,7 & 70,5 & 0,176770 & 0,382946 & 0,530016 & 0,368169 \\
\hline Czad & 643,7 & 6,8 & 43,2 & 0,147273 & 0,105426 & 0,314376 & 0,168125 \\
\hline Etiopia & 4177,3 & 5,6 & 39,8 & 1,000000 & 0,086822 & 0,287520 & 0,365291 \\
\hline Kazachstan & 61,3 & 0,0 & 3,4 & 0,006741 & 0,000000 & 0,000000 & 0,001685 \\
\hline Kirgistan & 525,9 & 8,0 & 84,8 & 0,118858 & 0,124031 & 0,642970 & 0,252472 \\
\hline Laos & 403,9 & 2,6 & 58,9 & 0,089418 & 0,040310 & 0,438389 & 0,152107 \\
\hline Lesotho & 114,3 & 4,4 & 51,2 & 0,019531 & 0,068217 & 0,377567 & 0,133383 \\
\hline Macedonia & 168,5 & 1,6 & 80,9 & 0,032607 & 0,024806 & 0,612164 & 0,173596 \\
\hline Malawi & 1279,3 & 23,5 & 68,7 & 0,300668 & 0,364341 & 0,515798 & 0,386287 \\
\hline Mali & 1246,0 & 8,9 & 67,2 & 0,292630 & 0,137984 & 0,503949 & 0,268137 \\
\hline Mołdawia & 328,0 & 3,1 & 92,4 & 0,071098 & 0,048062 & 0,781387 & 0,237152 \\
\hline Mongolia & 330,7 & 5,0 & 107,5 & 0,071738 & 0,077519 & 0,822275 & 0,262263 \\
\hline Nepal & 1078,4 & 12,8 & 36,8 & 0,252185 & 0,198450 & 0,263823 & 0,228227 \\
\hline Niger & 987,9 & 0,3 & 46,0 & 0,230350 & 0,004651 & 0,336493 & 0,144036 \\
\hline Paragwaj & 89,9 & 6,8 & 13,2 & 0,013637 & 0,105426 & 0,077409 & 0,075475 \\
\hline $\begin{array}{l}\text { Republika } \\
\text { Środkowej Afryki }\end{array}$ & 506,4 & 28,4 & 108,7 & 0,114153 & 0,440310 & 0,831754 & 0,456632 \\
\hline Rwanda & 1176,9 & 13,9 & 96,4 & 0,275937 & 0,215504 & 0,734597 & 0,360386 \\
\hline Suazi (Eswatini) & 150,1 & 4,0 & 109,8 & 0,028162 & 0,062016 & 0,840442 & 0,248159 \\
\hline Sudan Południowy & 1634,9 & 64,5 & 130,0 & 0,386468 & 1,000000 & 1,000000 & 0,846617 \\
\hline Tadżykistan & 340,8 & 4,1 & 38,2 & 0,074178 & 0,063566 & 0,274882 & 0,119048 \\
\hline Turkmenistan & 33,4 & 0,1 & 5,8 & 0,000000 & 0,001550 & 0,045814 & 0,012229 \\
\hline Uganda & 1817,4 & 7,4 & 42,4 & 0,430512 & 0,114729 & 0,308057 & 0,242007 \\
\hline Uzbekistan & 466,4 & 0,7 & 14,4 & 0,104486 & 0,010853 & 0,086888 & 0,053270 \\
\hline Zambia & 991,5 & 4,7 & 58,0 & 0,231197 & 0,072868 & 0,431280 & 0,202053 \\
\hline Zimbabwe & 669,5 & 4,4 & 40,5 & 0,153496 & 0,068217 & 0,293049 & 0,145745 \\
\hline
\end{tabular}

Źródło: obliczenia własne 
Tabela 8. Eksport produktu turystycznego i WEPTG w pozostałych LDCs w 2016 roku

\begin{tabular}{|c|c|c|c|c|c|c|c|}
\hline \multirow{2}{*}{ Państwo } & \multicolumn{3}{|c|}{ Eksport produktu turystycznego } & EPT & $\mathrm{EPT} / \mathrm{PKB}$ & $\begin{array}{c}\mathrm{EPT} \\
\text { per capita }\end{array}$ & \multirow{2}{*}{$\mathrm{WEPTG}_{\mathrm{LDC}}$} \\
\hline & $\begin{array}{l}\text { w mln } \\
\text { dol. }\end{array}$ & $\begin{array}{c}\text { do PNB } \\
(\%)\end{array}$ & $\begin{array}{l}\text { per capita } \\
\text { (w dol.) }\end{array}$ & \multicolumn{3}{|c|}{$\left(X-X_{\min }\right):\left(X_{\max }-X_{\min }\right)$} & \\
\hline Angola & 823,0 & 0,9 & 27,6 & 0,895539 & 0,113924 & 0,597403 & 0,430197 \\
\hline Bangladesz & 848,0 & 0,4 & 5,1 & 0,922742 & 0,050633 & 0,110390 & 0,283599 \\
\hline Benin & 141,0 & 1,6 & 12,6 & 0,153428 & 0,202532 & 0,272727 & 0,207805 \\
\hline Birma & 584,0 & 0,9 & 10,9 & 0,635473 & 0,113924 & 0,235931 & 0,274813 \\
\hline Dżibuti & 35,1 & 2,0 & 36,7 & 0,038194 & 0,253165 & 0,794372 & 0,334724 \\
\hline Erytrea & 0,0 & 0,0 & 0,0 & 0,000000 & 0,000000 & 0,000000 & 0,000000 \\
\hline Gambia & 76,2 & 7,9 & 36,3 & 0,082916 & 1,000000 & 0,785714 & 0,717158 \\
\hline Gwinea & 16,0 & 0,2 & 1,3 & 0,017410 & 0,025316 & 0,028139 & 0,024045 \\
\hline Gwinea-Bissau & 53,0 & 4,5 & 28,5 & 0,057671 & 0,569620 & 0,616883 & 0,453449 \\
\hline Haiti & 503,0 & 6,3 & 45,8 & 0,547334 & 0,797468 & 0,991342 & 0,783403 \\
\hline Jemen & 79,0 & 0,4 & 2,8 & 0,085963 & 0,050633 & 0,060606 & 0,061959 \\
\hline Kambodża & 740,0 & 3,7 & 46,2 & 0,805223 & 0,468354 & 1,000000 & 0,685483 \\
\hline $\begin{array}{l}\text { Kongo (Rep. } \\
\text { Demokratyczna) }\end{array}$ & 435,0 & 5,6 & 5,3 & 0,473341 & 0,708861 & 0,114719 & 0,501445 \\
\hline Liberia & 152,0 & 7,2 & 32,1 & 0,165397 & 0,911392 & 0,694805 & 0,670747 \\
\hline Madagaskar & 300,0 & 3,0 & 11,7 & 0,326442 & 0,379747 & 0,253247 & 0,334796 \\
\hline Mauretania & 74,0 & 1,6 & 16,7 & 0,080522 & 0,202532 & 0,361472 & 0,211764 \\
\hline Mozambik & 305,0 & 2,8 & 10,3 & 0,331882 & 0,354430 & 0,222944 & 0,315922 \\
\hline Senegal & 279,0 & 1,9 & 17,6 & 0,303591 & 0,240506 & 0,380952 & 0,291389 \\
\hline Sierra Leone & 34,0 & 1,0 & 4,5 & 0,036997 & 0,126582 & 0,097403 & 0,096891 \\
\hline Somalia & 0,0 & 0,0 & 0,0 & 0,000000 & 0,000000 & 0,000000 & 0,000000 \\
\hline Sudan & 203,0 & 0,2 & 5,0 & 0,220892 & 0,025316 & 0,108225 & 0,094938 \\
\hline Tanzania & 919,0 & 1,9 & 16,0 & 1,000000 & 0,240506 & 0,346320 & 0,456833 \\
\hline Togo & 53,0 & 1,2 & 6,8 & 0,057671 & 0,151899 & 0,147186 & 0,127164 \\
\hline
\end{tabular}

Źródło: obliczenia własne

Tabela 9. Pomoc rozwojowa i WPRG w pozostałych LDCs w 2016 roku

\begin{tabular}{|c|c|c|c|c|c|c|c|}
\hline \multirow{2}{*}{ Państwo } & \multicolumn{3}{|c|}{ Pomoc rozwojowa } & PR & $\mathrm{PR} / \mathrm{PNB}$ & $\begin{array}{c}\mathrm{PR} \\
\text { per canita }\end{array}$ & \multirow{2}{*}{$\mathrm{WPRG}_{\mathrm{LDC}}$} \\
\hline & $\begin{array}{c}\text { w mln } \\
\text { dol. }\end{array}$ & $\begin{array}{c}\text { do PNB } \\
(\%)\end{array}$ & $\begin{array}{c}\text { per capita } \\
\text { (w dol.) }\end{array}$ & \multicolumn{3}{|c|}{$\left(X-X_{\min }\right):\left(X_{\max }-X_{\min }\right)$} & \\
\hline Angola & 214,4 & 0,2 & 7,2 & 0,049193 & 0,000000 & 0,000000 & 0,012298 \\
\hline Bangladesz & 2535,9 & 1,1 & 15,4 & 1,000000 & 0,020179 & 0,043340 & 0,270925 \\
\hline Benin & 506,3 & 5,7 & 45,3 & 0,168718 & 0,123318 & 0,201374 & 0,154182 \\
\hline Birma & 1547,8 & 2,5 & 29,0 & 0,595279 & 0,051570 & 0,115222 & 0,203410 \\
\hline Dżibuti & 188,0 & 10,4 & 196,4 & 0,038344 & 0,228700 & 1,000000 & 0,373936 \\
\hline Erytrea & 133,4 & 5,2 & 29,8 & 0,015981 & 0,112108 & 0,119450 & 0,089912 \\
\hline Gambia & 94,3 & 9,8 & 44,9 & 0,000000 & 0,215247 & 0,199260 & 0,157438 \\
\hline Gwinea & 576,1 & 6,4 & 45,3 & 0,197308 & 0,139013 & 0,201374 & 0,169177 \\
\hline Gwinea-Bissau & 204,0 & 16,5 & 109,6 & 0,044902 & 0,365471 & 0,541226 & 0,329267 \\
\hline Haiti & 1087,1 & 13,3 & 99,0 & 0,406615 & 0,293722 & 0,485201 & 0,369815 \\
\hline Jemen & 1971,9 & 7,1 & 69,8 & 0,768974 & 0,154709 & 0,330867 & 0,352315 \\
\hline
\end{tabular}




\begin{tabular}{|l|r|r|r|r|r|r|r|}
\hline Kambodża & 741,0 & 3,9 & 46,3 & 0,264868 & 0,082960 & 0,206660 & 0,159362 \\
\hline $\begin{array}{l}\text { Kongo (Rep. } \\
\text { Demokratyczna) }\end{array}$ & 1390,9 & 1,2 & 17,1 & 0,531040 & 0,022422 & 0,052326 & 0,157052 \\
\hline Liberia & 835,7 & 44,8 & 176,6 & 0,303629 & 1,000000 & 0,895349 & 0,799745 \\
\hline Madagaskar & 639,3 & 6,5 & 25,0 & 0,223191 & 0,141256 & 0,094080 & 0,149946 \\
\hline Mauretania & 298,8 & 6,3 & 67,6 & 0,083740 & 0,136771 & 0,319239 & 0,169130 \\
\hline Mozambik & 1575,4 & 14,2 & 53,1 & 0,606610 & 0,313901 & 0,242600 & 0,369253 \\
\hline Senegal & 757,7 & 5,2 & 47,8 & 0,271686 & 0,112108 & 0,214588 & 0,177622 \\
\hline Sierra Leone & 708,1 & 21,9 & 93,7 & 0,251376 & 0,486547 & 0,457188 & 0,420415 \\
\hline Somalia & 1204,5 & 17,4 & 81,7 & 0,454692 & 0,385650 & 0,393763 & 0,404939 \\
\hline Sudan & 798,5 & 0,9 & 19,7 & 0,288405 & 0,015695 & 0,066068 & 0,096466 \\
\hline Tanzania & 2389,8 & 4,9 & 41,7 & 0,940165 & 0,105381 & 0,182347 & 0,333319 \\
\hline Togo & 169,2 & 3,6 & 21,7 & 0,030669 & 0,076233 & 0,076638 & 0,064944 \\
\hline
\end{tabular}

Źródło: obliczenia własne

W wyniku aplikacji danych za 2016 rok - zob. tabele 4, 5, 6, 7, 8 i 9 - stwierdzić należy, że w 66 z 83 analizowanych państw uzyskane wskaźniki osiągnęły wartości do 0,6 WEPTG oraz do 0,4 w przypadku WPRG. W pozostałych państwach - w $11 \mathrm{z}$ nich wskaźnik eksportu produktu turystycznego w gospodarce był wyższy od 0,6 (Malediwy, Azerbejdżan, Haiti, Armenia, Gambia, Botswana, Kambodża, Liberia, Antigua i Barbuda, Palau oraz Bahamy), a w siedmiu państwach wskaźnik pomocy rozwojowej w gospodarce był wyższy od 0,4 (Sudan Południowy, Liberia, Tuvalu, Afganistan, Republika Środkowej Afryki, Sierra Leone oraz Somalia). W przypadku jednego państwa (Liberia) oba wskaźniki osiągnęły wysokie wartości - zob. rycina 1 oraz tabele 1, 2 i 3.

W małych, rozwijających się państwach wyspiarskich wartości obu uzyskanych wskaźników wykazały specyficzną zależność. W większości SIDS jeden ze wskaźników był średniowysoki bądź wysoki, przy drugim (względnie) niskim - por. rycina 1. Przy wysokim WEPTG m.in. na Malediwach $(0,981593)$, na Antigui i Barbudzie $(0,650323)$, na Palau $(0,643411)$ czy na Bahamach $(0,627506)$ drugi wskaźnik (WPRG) był niski bądź bardzo niski - w niektórych przypadkach pomoc rozwojowa nie była statystycznie znacząca. Podobne wnioski dotyczyć mogą innych państw o średniowysokim WEPTG (m.in. Grenada, St. Lucia, St. Kitts i Nevis, Seszele, Dominika, Jamajka, Barbados, Mauritius). W SIDS występuje również zależność odwrotna. Przy najwyższych wartościach WPRG na Tuvalu $(0,785868)$ uzyskany WEPTG był niski $(0,056575)$. Podobna sytuacja występowała w innych małych państwach wyspiarskich - m.in. na Wyspach Salomona, Timorze Wschodnim i Nauru. W tych przypadkach dysproporcje nie były jednak tak znaczne jak w przypadku państw o wysokim WEPTG i niskim WPRG - por. rycina 1, tabela 1.

W grupie rozwijających się państw bez dostępu do morza dominujące wartości obu wskaźników znajdowały się w przedziale WEPTG do 0,6 oraz WPRG do 0,4. Jakkolwiek występowały nieliczne przypadki (charakterystyczne dla SIDS) o skrajnie wysokim jednym ze wskaźników, przy jednocześnie drugim niskim (bądź względnie niskim). Tego typu państwami były szczególnie: Azerbejdżan (WEPTG - 0,803254; WPRG 0,013122), Armenia (WEPTG - 0,766259; WPRG - 0,254848), Botswana (WEPTG 0,711154; WPRG - 0,0810762) oraz Sudan Południowy (WEPTG - 0,045624; WPRG 0,846617), Afganistan (WEPTG - 0,021170; WPRG - 0,634031) czy Republika Środkowej Afryki (WEPTG - 0,226820; WPRG - 0,456632) - zob. rycina 1, tabela 2. 
Rycina 1. WEPTG i WPRG w SIDS, LLDCs i LDCs w 2016 roku

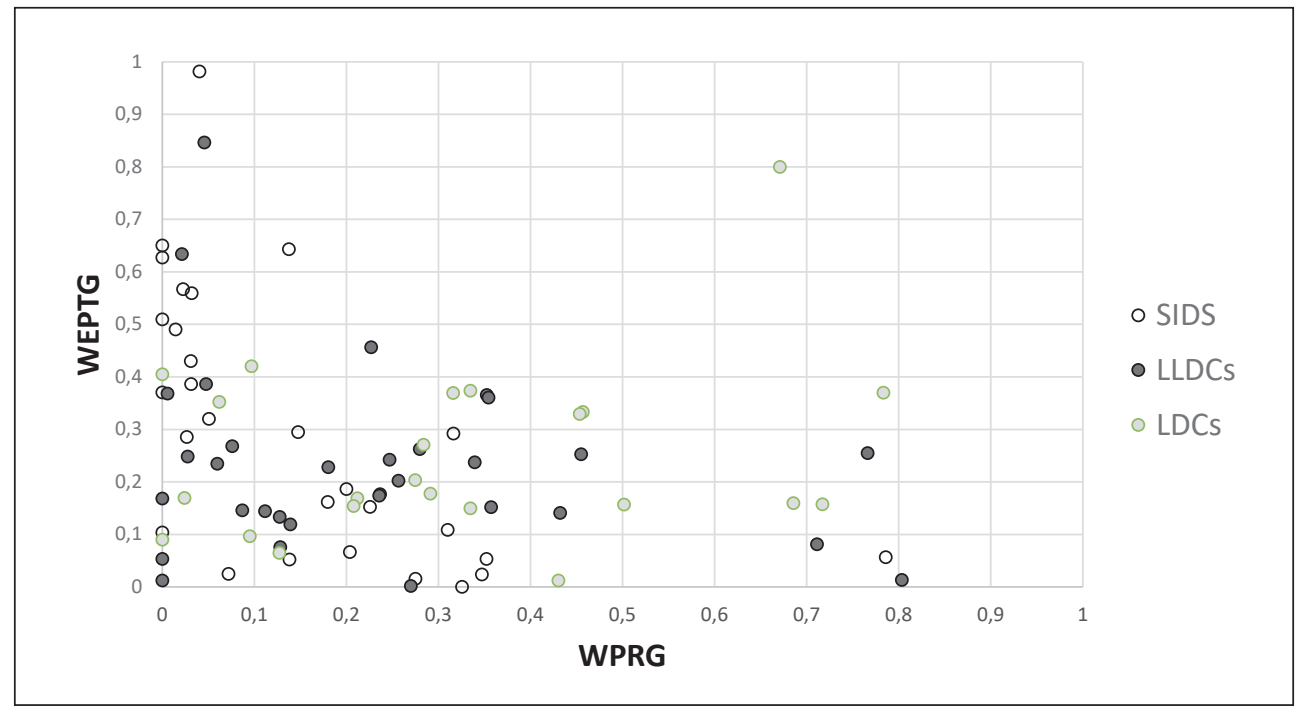

Źródło: obliczono na podstawie Bank Światowy (2018)

Jeśli chodzi o pozostałe państwa najsłabiej rozwinięte ${ }^{3}$, to w większości przypadków uzyskane wartości obu wskaźników znajdowały się w przedziale WEPTG do 0,6 oraz WPRG do 0,4, podobnie jak w przypadku SIDS i LLDCs. Dla tej grupy osobliwe były szczególnie dwa przypadki, w których oba wskaźniki były wysokie - Liberia (WEPTG 0,670747; WPRG - 0,799745) oraz Haiti (WEPTG - 0,783403; WPRG - 0,369815). Istotne jest również wskazanie na „turystyczne” LDCs (Gambia i Kambodża) - państwa o wysokim wskaźniku eksportu produktu turystycznego w gospodarce (odpowiednio 0,717158 oraz 0,685483), przy jednocześnie (względnie) niskim (poniżej 0,2) wskaźniku pomocy rozwojowej w gospodarce oraz na „pomocowe” LDCs (Sierra Leone i Somalia) o WPRG powyżej 0,4 - zob. rycina 1 , tabela 3 .

\section{TURYSTYKA A POMOC ROZWOJOWA W PROCESIE ROZWOJU SPOŁECZNO- -EKONOMICZNEGO W PAŃSTWACH O NIEKORZYSTNYM POŁOŻENIU GEOGRAFICZNYM ORAZ NAJSŁABIEJ ROZWINIĘTYCH}

Specyfika państw Południa o niekorzystnym położeniu geograficznym oraz najsłabiej rozwiniętych skłania do alternatywnego podejścia do analizy działalności gospodarczej. Jest nim szeroko rozumiany rozwój społeczny - mieszczący w sobie zagadnienia wzrostu i rozwoju gospodarczego (por. Bartkowiak, 2013; Mirkowska-Ostatek, 2013). Perspektywa ta, wywodząca się z koncepcji A. Sena (2002), znalazła uznanie i jest powszechnie akceptowana w literaturze przedmiotu. Metodą oceny efektywności tak rozumianego gospodarowania jest wskaźnik rozwoju społecznego (HDI).

Na podstawie analizy wysokości tego wskaźnika w 2017 roku w 80 badanych państwach (na podstawie: UNDP, 2018) stwierdzić należy, że w trzech był on bardzo wysoki

\footnotetext{
${ }^{3}$ Najsłabiej rozwinięte państwa o niekorzystnym położeniu geograficznym zostały zaklasyfikowane w badaniu do SIDS i LLDCs. Pozostałe LDCs to państwa, które nie mają cech SIDS i LLDCs - zob. tabele 3, 8 i 9.
} 
(powyżej 0,799). Dwa z nich są małymi państwami wyspiarskimi (Bahamy i Barbados) oraz jedno jest śródlądowe (Kazachstan). Do państw o wysokim HDI (od 0,700 do 0,799) zaklasyfikowano 25, z czego 16 to SIDS (od najwyższego HDI: Palau, Seszele, Mauritius, Trynidad i Tobago, Antigua i Barbuda, St. Kitts i Nevis, Grenada, St. Lucia, Fidżi, Jamajka, Wyspy Tonga, St. Vincent i Grenadyny, Malediwy, Dominika, Samoa oraz Wyspy Marshalla), dziewięć to LLDCs (od najwyższego HDI: Azerbejdżan, Macedonia, Armenia, Mongolia, Botswana, Uzbekistan, Turkmenistan, Paragwaj oraz Mołdawia). Do państw o średnich wartościach HDI (od 0,555 do 0,699) zaliczono 18, z czego 14 to państwa o niekorzystnym położeniu geograficznym (osiem LLDCs: Boliwia, Kirgistan, Tadżykistan, Bhutan, Laos, Suazi, Zambia, Nepal, oraz sześć SIDS: Republika Zielonego Przylądka, Federacyjne Stany Mikronezji, Timor Wschodni, Kiribati, Vanuatu oraz Wyspy Świętego Tomasza i Książęca), a cztery to tzw. pozostałe LDCs (Bangladesz, Kambodża, Angola i Birma). W 34 państwach wskaźnik HDI był niski (poniżej 0,554). W trzech przypadkach (Nauru, Somalia i Tuvalu) brak było danych do jego wyliczenia - zob. tabele 1, 2 i 3.

Niekorzystne geograficzne uwarunkowania rozwoju, szczególnie w przypadku SIDS, nie zawsze determinują jego niski poziom. Paradoksalnie, w 18 na 28 małych państw wyspiarskich rozwój społeczno-gospodarczy jest bardzo wysoki (karaibskie: Bahamy, Barbados) i wysoki. Odwołując się do wcześniej analizowanych wskaźników eksportu produktu turystycznego i pomocy rozwojowej w gospodarce, stwierdzić należy, że w grupie najbardziej rozwiniętych i najzamożniejszych SIDS dominuje turystyczna specjalizacja rozwojowa. Jest to szczególnie widoczne na: Malediwach, Antigui i Barbudzie, Palau, Bahamach, Grenadzie, St. Lucii, St. Kitts i Nevis, Seszelach, Dominice, Jamajce, Barbadosie i Mauritiusie (wysoki WEPTG: od 0,981593 do 0,319936). Z drugiej strony państwa te bądź nie korzystają ze środków pomocowych, bądź robią to w niewielkim stopniu (największy WPRG w 2016 roku był na Palau i wynosił 0,137483 ) - por. tabele 1,4 i 5.

W przypadku tych SIDS, które w dużym stopniu opierają się na pomocy rozwojowej (wysoki WPRG), poziom ich rozwoju jest z reguły średni bądź niski. Tego typu państwami są (oceaniczne): Tuvalu, Wyspy Salomona, Timor Wschodni, Nauru, Vanuatu, Kiribati, Federacyjne Stany Mikronezji. Wyjątek stanowią Wyspy Tonga oraz Samoa, gdzie przy średnim WPRG (odpowiednio: 0,309966 i 0,225503) poziom rozwoju jest wysoki (HDI: 0,726 i 0,713) - zob. tabele 1 i 5 . Niemniej we wszystkich wymienionych przypadkach (za wyjątkiem Tuvalu) WEPTG jest niski - turystyka nie jest znaczącym źródłem pozyskiwania dewiz dla tych państw - por. tabela 4.

Potwierdza to wcześniejsze wyniki badań autora (Jasiński, 2010, 2017b, 2018b), z których nasuwa się wniosek, że intensywny rozwój gospodarki turystycznej prowadzący często w SIDS do zjawiska monokultury turystycznej (Giezgała, 1969, 1977; Wodejko, 1989, 1998; Kachniewska, Niezgoda, Pawlicz, 2012) przyczynia się do przełamania stagnacji gospodarczej i wejścia na ścieżkę „niezrównoważonego” rozwoju. Pomimo licznych kontrowersji (negatywnych zjawisk na płaszczyźnie społecznej, ekologicznej, jak i ekonomicznej) - próbując dokonać ekonomicznej oceny monokultury turystycznej czy też modelu rozwoju SITE ${ }^{4}$ (McElroy, 2006; McElroy, Parry, 2010) stwierdzić należy, że ta ścieżka rozwoju spowodowała w ostatnich dziesięcioleciach osiągnięcie znacznego (bardzo wysokiego i wysokiego) poziomu rozwoju przez część

${ }^{4}$ Model rozwojowy SITE jest akronimem od słów: małe (small), wyspiarskie (island), gospodarki turystyczne (tourist, economies). Dominującym źródłem wpływów z zagranicy takiej gospodarki jest turystyka międzynarodowa. 
SIDS (szczególnie Antigua i Barbuda, Bahamy, Barbados, Mauritius, Seszele) oraz dynamiczne „doganianie” państw wysokorozwiniętych (w ostatnich 10-20 latach) przez inne SIDS (szczególnie Malediwy i Palau).

Jako dodatkowy argument przemawiający na korzyść specjalizacji turystycznej przytoczyć można małe państwa wyspiarskie, które nie rozwijając intensywnie gospodarki turystycznej, opierają ekonomiczną egzystencję na innym modelu - MIRAB ${ }^{5}$ (Bertram, Watters, 1984, 1985, 1986; Bertram, 2006) - sprowadzającym się do funkcjonowania dzięki pomocy z zewnątrz (pomoc rozwojowa, przekazy od emigrantów). Państwa te - pomimo że od wielu dziesięcioleci otrzymują pomoc rozwojową doprowadzającą do zakleszczenia w monokulturze rozwojowej, przy nadal wysokim WPRG cechuje stagnacja (m.in. Timor Wschodni, Tuvalu czy Wyspy Salomona) - patrz: tabele 1 i 5. Prowadzić to może do konkluzji, że w tych przypadkach mamy do czynienia ze zdumiewającym paradoksem: im obficiej płyną środki pomocowe do danego SIDS, tym bardziej rośnie prawdopodobieństwo, że państwo to będzie się wolniej rozwijało (Jasiński, 2017a, 2017b, 2017c, 2018b; Jasiński, Górska, 2018).

Rozwijające się państwa śródlądowe są silniej rozwarstwione pod względem poziomu rozwoju społecznego i zamożności niż SIDS - por. tabele 1 i 2 . Są one również bardziej zróżnicowane pod względem uwarunkowań rozwojowych niż małe państwa wyspiarskie. Są wśród nich obszary zarówno duże powierzchniowo - m.in. Kazachstan $\left(2724,9\right.$ tys. $\left.\mathrm{km}^{2}\right)$, Czad (1284,0 tys. $\left.\mathrm{km}^{2}\right)$, Niger $\left(1267,0\right.$ tys. $\left.\mathrm{km}^{2}\right)$, Mali $\left(1240,2\right.$ tys. $\left.\mathrm{km}^{2}\right)$ czy Etiopia $\left(1104,3\right.$ tys. $\left.\mathrm{km}^{2}\right)$, jak i państwa małe - m.in. Armenia $\left(29,7\right.$ tys. $\left.\mathrm{km}^{2}\right)$, Burundi $\left(27,8\right.$ tys. $\left.\mathrm{km}^{2}\right)$, Rwanda $\left(26,3\right.$ tys. $\left.\mathrm{km}^{2}\right)$, Macedonia $\left(25,7\right.$ tys. $\left.\mathrm{km}^{2}\right)$ oraz Suazi (Eswatini) ${ }^{6}\left(17,4\right.$ tys. $\left.\mathrm{km}^{2}\right)$. Są państwa o dużej populacji (w 2017 roku) - m.in. Etiopia (105,0 mln), Uganda (42,9 mln), Afganistan (35,5 mln), Uzbekistan $(32,4 \mathrm{mln})$ oraz Nepal $(29,3 \mathrm{mln})$, jak i o niewielkiej - m.in. Botswana $(2,3 \mathrm{mln})$, Lesotho $(2,2 \mathrm{mln})$, Macedonia $(2,1 \mathrm{mln})$, Suazi $(1,4 \mathrm{mln})$ czy Bhutan (0,9 mln) (Bank Światowy, 2018).

Odmienność uwarunkowań i barier rozwojowych LLDCs w porównaniu z małymi państwami wyspiarskimi, w tym szczególnie (przynajmniej w teorii) większa możliwość specjalizacji gospodarczej, skłania do zastanowienia, czy w przypadku niektórych państw śródlądowych występuje zjawisko monokultury turystycznej. Analizując to zagadnienie przez pryzmat poziomu rozwoju (a jest to istotne przy specjalizacji proturystycznej na współczesnym międzynarodowym rynku turystycznym ${ }^{7}$ ), stwierdzić należy, że w najwyżej rozwiniętych i najzamożniejszych państwach bez dostępu do

\footnotetext{
${ }^{5}$ MIRAB - jest akronimem od: Mi - migration (migracje), R - remittances (przekazy), A - aid (pomoc), B - bureaucracy (biurokracja). W obrazowy sposób ukazuje on zasadę funkcjonowania takiej gospodarki. Dominującymi źródłami gospodarowania są dwa elementy. Pierwszym jest migracja zarobkowa znacznej części mieszkańców wysp do państw o dużo wyższym poziomie rozwoju gospodarczego i przesyłanie (przekazy) nabytych środków finansowych (czy też rzeczowych). Drugim jest otrzymywanie pomocy rozwojowej, do której (wraz z jej wzrostem) potrzebna jest coraz większa liczba urzędników do jej wdrażania (rozrost biurokracji).

${ }^{6} \mathrm{Z}$ dniem 1 czerwca 2018 roku Suazi (Swaziland) zmieniło formalnie nazwę na Królestwo Eswatini (the Kingdom of Eswatini), w wyniku tego na potrzeby artykułu stosowane są obie nazwy (Suazi/Eswatini) - por. tabele 2,6 i 7.

${ }^{7}$ Proeksportowa strategia turystyczna wymaga rozwoju przede wszystkim infrastruktury turystycznej (wynikającej często ze stanu infrastruktury ogólnej) - w celu stworzenia konkurencyjnego na światowym rynku produktu turystycznego. Podstawową zaletą strategii turystycznej jest możliwość „eksportu” zasobów przyrody, których nie można „sprzedać” w inny sposób (np. $3 \times \mathrm{S}-$ sun, sea, sand) oraz pozyskiwanie z tego tytułu wpływów dewizowych - co jest często podnoszonym argumentem dla zwolenników turystycznej ścieżki rozwoju w przypadku SIDS.
} 
morza (m.in. Kazachstan, Macedonia, Azerbejdżan, Armenia, Mongolia, Botswana) wpływy z turystyki są znaczące dla gospodarki. Jest to wyraźne szczególnie w Azerbejdżanie (WEPTG 0,766259) i Botswanie (WEPTG 0,711154).

Analizując to zagadnienie bardziej wnikliwie, stwierdzić należy, że pomimo wysokich wpływów z eksportu produktu turystycznego m.in. w Azerbejdżanie ( 2 855,0 mln USD), Etiopii (2 138,0 mln USD), Kazachstanie (1 716 mln USD) oraz Botswanie (1 075 mln USD) - porównywalnych (zob. tabele 4 i 6) z najwyższymi wpływami w podgrupie SIDS (Malediwy, Bahamy, Jamajka, Mauritius, Fidżi) - nie można mówić w przypadku wymienionych LLDCs o monokulturze turystycznej. Odnosząc EPT do całej gospodarki, jest to szczególnie wyraźne. W przypadku „turystycznych” SIDS mamy do czynienia z dwucyfrowym miernikiem EPT/PKB ${ }^{8}$ (zob. tabela 4). Wśród państw bez dostępu do morza żadne z nich nie ma tego miernika na tak wysokim poziomie (zob. tabela 6). Wskazuje to, że - pomimo istotnego znaczenia wpływów z turystyki PKB tworzone jest przez inne rodzaje działalności. Jest to również widoczne przy odwołaniu się do miernika EPT per capita. W „turystycznych” SIDS jest on mierzony w tysiącach dolarów, w LLDCs nie osiąga tych wartości - por. tabele 4 i 6.

Resumując ten wątek, stwierdzić należy, że na zjawisko monokultury turystycznej podatne są tylko małe państwa wyspiarskie. W małych śródlądowych gospodarkach teoretycznie najbardziej podatnych na wystąpienie tego zjawiska - nie ma przesłanek do stwierdzenia, że ono występuje. W dużych i średnich LLDCs (pomimo znacznych wpływów w części nich z EPT) - również takich przesłanek nie ma. Podobne wnioski można odnieść do pozostałych państw najsłabiej rozwiniętych. Choć w niektórych przypadkach turystyka stanowi co prawda znaczące źródło pozyskiwania dewiz (i paradoksalnie poziom ich rozwoju nie jest wysoki), m.in. w Tanzanii, Bangladeszu, Angoli, Kambodży, Birmie, Haiti i Demokratycznej Republice Konga (por. tabele 3 i 8), to jednak nie można mówić o tych państwach jako o monokulturach turystycznych.

Istotne z perspektywy rozważań jest również uwzględnienie znaczenia pomocy rozwojowej $\mathrm{w}$ badanych państwach $\mathrm{w}$ procesie przełamania zacofania. Zagadnienie to wpisuje się w szeroki nurt dyskusji w światowej literaturze przedmiotu dotyczącej skuteczności pomocy rozwojowej (Easterly, 2006; Moyo, 2009; Leszczyński, 2016) i - podobnie jak w przypadku monokultury turystycznej - jest kontrowersyjne. Powracając bowiem do wątku paradoksu SIDS gospodarujących według modelu MIRAB (w których, jak nadmieniono, pomimo przekazywania im w długim okresie znacznych ilości środków pomocowych, rozwój nie następuje), można zadać pytanie, czy podobne mechanizmy mogą zachodzić w pozostałych badanych państwach.

Mierniki cząstkowe (PR, PR/PNB, PR per capita) i WPRG wskazują, że w części państw pomoc rozwojowa jest istotnym źródłem środków z zagranicy. Wpływy z tego tytułu w niektórych państwach są dużo wyższe (Afganistan, Etiopia) niż te osiągane z eksportu produktu turystycznego w SIDS. W części zaś (pomimo niższych wpływów z PR) można mówić o występowaniu zjawiska monokultury pomocowej (Jasiński, 2017a, 2017b, 2017c, 2018a; Jasiński, Górska, 2018) - m.in. w Sudanie Południowym, Tuvalu, Liberii, Republice Środkowej Afryki, Burundi, Malawi, Sierra Leone, Wyspach Tonga, Kiribati czy Nauru - zob. tabele 5, 7 i 9. Wskazuje to, że w przeciwieństwie do charakterystycznej tylko dla SIDS „monokultury turystycznej” - „monokultura

${ }^{8}$ Za umowną wartość, kiedy gospodarka staje się „zależna” od eksportu produktu turystycznego (kiedy zaczyna być monokulturą turystyczną), w literaturze przedmiotu przyjęto w latach osiemdziesiątych XX wieku przekroczenie 20\% EPT w PKB, w latach dziewięćdziesiątych XX wieku 25\% (Wodejko, 1989, 1998). 
pomocowa" występuje również w państwach dużych, zarówno bez dostępu do morza, jak i w tych, które go mają.

Reasumując oba poruszone wątki, należy stwierdzić, że ekonomiczna ocena monokultury turystycznej jest bardzo trudna i pomimo przedstawionych pozytywnych przesłanek - raczej krytyczna. W szerszym kontekście podstawowym argumentem na niekorzyść jest bezpieczeństwo ekonomiczne. SIDS z jednostronnie rozwiniętą gospodarką turystyczną narażone są na różnego rodzaju szoki i wstrząsy z zewnątrz, o wiele silniejsze, niż gdyby gospodarka była bardziej zdywersyfikowana. Co by się stało w przypadku masowego odpływu ruchu turystycznego? Bez względu na to, czy przyczyny byłyby natury ekonomicznej, politycznej, zdrowotnej, czy związane z zagrożeniem terrorystycznym - oznaczałoby to katastrofę ekonomiczną dla tych SIDS.

Wypieranie przez działalność turystyczną innych sektorów gospodarki ${ }^{9}$, szczególnie rolnictwa i rybołówstwa (tradycyjnego w przeszłości dla SIDS), tak wyraźnego w małych państwach wyspiarskich, wydaje się być raczej błędne. Jakkolwiek można znaleźć przykłady SIDS na świecie, które odniosły sukces (choć dyskusyjny) w oparciu o eksport produktu turystycznego (m.in. Antigua i Barbuda, Bahamy, Barbados). Sukces w tej grupie wynikał ze specyficznego - mądrego (kontrolowanego) zarządzania sektorem turystycznym. W przypadku Bahamów stanowił on konieczną fazę rozwoju usług finansowych - podobnie jak w przypadku Barbadosu, Seszeli czy Mauritiusa. Z tym że w tych ostatnich państwach charakterystyczne było „podpieranie” się rolnictwem. Monokultura turystyczna nigdy $w$ tych trzech państwach nie była silna.

Podobne wątpliwości można mieć szczególnie w stosunku do najbardziej ekstremalnych monokultur turystycznych - Malediwów i Palau. Silna presja na zwiększanie wpływów z EPT na Malediwach i Palau powoduje nie tylko liczne negatywne zjawiska (koszty) na płaszczyźnie społecznej i ekologicznej, ale i ekonomicznej. Jest to szczególnie widoczne w pierwszym z państw, które - dzięki wzrostowi gospodarczemu pobudzonemu przez turystykę - wyszło (w przeciągu kilku lat) z grupy państw najsłabiej rozwiniętych i dołączyło (przynajmniej statystycznie) do najbardziej zamożnych SIDS. Rozwój gospodarki turystycznej na Malediwach przebiega jednak według specyficznego modelu izolacji, charakteryzującego się m.in. brakiem udziału w zyskach z tego tytułu przez ludność lokalną (Jędrusik, 2003). Odzwierciedleniem tego jest duża dysproporcja pomiędzy zamożnością a rozwojem społecznym w tym państwie (por. tabela 1). Tempo wzrostu gospodarczego nie przekłada się na „poprawę standardów cywilizacyjnych i polepszenie bytu ludności" (Piasecki, 2003: 16) - co stanowić powinno kwintesencję rozwoju w przypadku państw Południa.

Analogiczne zastrzeżenia można mieć do „monokultury pomocowej” - choć w przeciwieństwie do monokultury turystycznej wydaje się ona zjawiskiem niosącym ze sobą większe zagrożenie. Oprócz negatywnych mechanizmów wynikających z choroby holenderskiej występuje dodatkowo specyficzne zjawisko ubezwłasnowolnienia, będące pochodną (szczególnie w przeszłości) charakteru świadczonej przez Północ pomocy rozwojowej. Jak trafnie zauważa D.S. Landes, przytaczając afrykańskie przysłowie: „Ręka, która bierze, jest zawsze pod tą, która daje” (Landes, 2007: 584).

\footnotetext{
${ }^{9}$ Analizując monokulturę turystyczną i „pomocową” z perspektywy koncepcji wypracowanych przez ekonomię międzynarodową, stwierdzić można, że rozwój gospodarki turystycznej, jaki i pomoc rozwojowa mogą w szczególnych przypadkach przyczynić się do wystąpienia choroby holenderskiej (Dutch disease) zjawiska powodującego m.in. regres niektórych działów gospodarki oraz spadek dywersyfikacji wywozu i nadmierne uzależnienie eksportu oraz gospodarki państwa od wpływów ze sprzedaży jednego czy kilku surowców (monokultura). Szerzej zob. A. Budnikowski (2017).
} 


\section{PODSUMOWANIE}

Zgodnie z koncepcją UNCTAD (2018) w artykule wyróżniono 83 państwa Południa, które pogrupowano z uwzględnieniem ich charakterystycznych cech na: małe państwa wyspiarskie (SIDS), państwa bez dostępu do morza (LLDCs) oraz państwa najsłabiej rozwinięte (LDCs). W przypadku dwóch pierwszych grup za podstawową barierę rozwoju uznano czynniki geograficzne, stąd na potrzeby analizy określono je państwami o niekorzystnym położeniu geograficznym. Następnie zarysowano podstawowe, charakterystyczne dla badanych grup problemy rozwojowe.

W celu wykazania ekonomicznego znaczenia proeksportowej specjalizacji turystycznej i pomocy rozwojowej dla poszczególnych grup na potrzeby badania, skonstruowano dwa wskaźniki: eksportu produktu turystycznego w gospodarce (WEPTG) oraz pomocy rozwojowej w gospodarce (WPRG). W wyniku aplikacji danych (za 2016 rok) w 66 państwach uzyskano wartości do 0,6 w przypadku pierwszego wskaźnika oraz do 0,4 w przypadku WPRG. W pozostałych 11 - WEPTG w gospodarce był wyższy oraz w siedmiu wskaźnik pomocy rozwojowej w gospodarce był wyższy od uzyskanego w dominującej liczbie państw. W jednym przypadku oba wskaźniki osiągnęły wysokie wartości.

W grupie SIDS zaobserwowano specyficzną zależność pomiędzy wartościami WEPTG i WPRG. W większości przypadków jeden ze wskaźników był średniowysoki bądź wysoki przy drugim względnie niskim. Szczególnie było to wyraźne przy zależności wysoki WEPTG « niski WPRG. W grupie państw śródlądowych zaobserwowano również podobną zależność, ale w nielicznych (sześciu) przypadkach. W pozostałych LDCs nie zaobserwowano tego typu relacji. W tej grupie państw występowały natomiast dwa przypadki, które charakteryzowały się jednocześnie wysokimi wartościami WEPTG i WPRG.

Następnie, przy zastosowaniu wskaźnika HDI i miernika cząstkowego dochodu na per capita, dokonano klasyfikacji badanych państw pod kątem ich poziomu rozwoju społeczno-ekonomicznego. Badanie wykazało, że na 83 analizowane państwa: trzy (Bahamy, Barbados i Kazachstan) należą do grupy najwyżej rozwiniętych; 25 do wysokorozwiniętych (z czego 16 to SIDS, a 9 to LLDCs); 18 do średnio rozwiniętych (z czego 14 to państwa o niekorzystnym położeniu geograficznym, a cztery to LDCs); pozostałe (37) uznano za słabo rozwinięte.

Wyniki powyższych badań umożliwiły potwierdzenie postawionej tezy, która zakładała, że rozwój gospodarki turystycznej i związany z nią eksport produktu turystycznego był większy i bardziej znaczący dla procesów pobudzenia rozwoju w państwach o wyższym jego poziomie. W przypadkach zaś niskiego poziomu rozwoju większe znaczenie (i wyższe wpływy) były z pomocy rozwojowej.

Dalsza analiza potwierdziła, że zjawisko „monokultury turystycznej” jest charakterystyczne tylko dla grupy SIDS. W przypadkach LLDCs i LDCs nie stwierdzono znamion tego zjawiska. Natomiast monokultura pomocowa występuje nie tylko w części małych państw wyspiarskich, ale również w niektórych państwach z grupy LLDCs i LDCs (o większym potencjale rozwojowym). Za zjawisko niosące ze sobą większe zagrożenie z perspektywy rozwojowej uznano drugie z nich.

\section{Literatura \\ References}

Bank Światowy (2018). Pozyskano z https://data.worldbank.org/ 
Bartkowiak, R. (2013). Ekonomia rozwoju. Warszawa: Polskie Wydawnictwo Ekonomiczne.

Bertram, G. (2006). Introduction: The MIRAB model in the twenty-first century. Asia Pacific Viewpoint, 47(1), 1-13.

Bertram, G., Watters, R.F. (1984). New Zealand and its Small Island Neighbours: A Review of New Zealand Policy Toward the Cook Islands, Niue, Tokelau, Kiribati and Tuvalu. Wellington: Institute of Policy Studies, Victoria University of Wellington.

Bertram, G., Watters, R.F. (1985). The MIRAB Economy in South Pacific Microstates. Pacific Viewpoint, 26(3), 497-519.

Bertram, G., Watters, R.F. (1986). The MIRAB Process: Earlier Analysis in Context. Pacific Viewpoint, 27(1), 47-59.

Budnikowski, A. (2017). Ekonomia międzynarodowa. Warszawa: Polskie Wydawnictwo Ekonomiczne.

Czaplicka, K. (2007). Wzrost i rozwój gospodarczy w krajach rozwijających się. W: R. Piasecki (red.). Ekonomia rozwoju. Warszawa: Polskie Wydawnictwo Ekonomiczne.

Dudziński, J. (1986). Najsłabiej rozwinięte kraje Trzeciego Świata. Szczecin: Wydawnictwo Glob.

Dudziński, J. (1992). Położenie geograficzne jako bariera rozwoju ekonomicznego. Szczecin: Wydawnictwo Uniwersytetu Szczecińskiego.

Easterly, W. (2006). The White Man's Burden. Why the West's Efforts to Aid the Rest Have Done so Much Ill and so Little Good. Oxford: Oxford University Press.

Encontre, P. (2004). SIDS as a category: adopting criteria would enhance credibility. W: Is a special treatment of small island developing States possible? UNCTAD.

Faye, M.L., McArthur, J.W., Sachs, J.D., Snow, T. (2004). Challenges Facing Landlocked Developing Countries. Journal of Human Development, 5(1), 31-68.

Garbicz, M. (2012). Problemy rozwoju i zacofania ekonomicznego. Dlaczego jedne kraje sq biedne, podczas gdy inne sq bogate? Warszawa: Oficyna a Wolters Kluwer Business.

Giezgała, J. (1969, 1977). Turystyka w gospodarce narodowej. Warszawa: Polskie Wydawnictwo Ekonomiczne.

Hein, P. (2004). Small island developing States: origin of the category and definition issues. W: Is a special treatment of small island developing States possible? UNCTAD.

Jasiński, M. (2010). Teoria zależności od ścieżki a małe gospodarki wyspiarskie. Zeszyty Naukowe Kolegium Gospodarki Światowej Szkoły Głównej Handlowej w Warszawie, 28, 52-72.

Jasiński, M. (2017a). Aspekty monokulturowe pomocowej choroby holenderskiej. Kwartalnik Kolegium Ekonomiczno-Społecznego Szkoły Głównej Handlowej w Warszawie. Studia i Prace, 3(31), 151-167.

Jasiński, M. (2017b). Modele rozwoju gospodarczego a poziom rozwoju społecznego i zamożności w małych państwach wyspiarskich na świecie. Studia i Prace. Wydział Nauk Ekonomicznych i Zarzq̨dzania Uniwersytetu Szczecińskiego, 49(2), 317-333.

Jasiński, M. (2017c). Poziom rozwoju społecznego i zamożności a pomoc rozwojowa i przekazy w państwach o niekorzystnym położeniu geograficznym. W: J. Szlachta, M. Zaleska, K. Żukrowska, R. Towalski (red.). Społeczny kontekst ekonomii. Warszawa: Oficyna Wydawnicza Szkoła Główna Handlowa w Warszawie.

Jasiński, M. (2018a). Kirgiski syndrom MIRAB. Studia i Prace. Wydział Nauk Ekonomicznych i Zarządzania Uniwersytetu Szczecińskiego, 53(2), 37-52.

Jasiński, M. (2018b). Nasycenie gospodarki turystyką a poziom rozwoju społeczno-ekonomicznego w małych rozwijających się państwach wyspiarskich. Prace Komisji Geografii Przemysłu Polskiego Towarzystwa Geograficznego, 32(2), 311-324.

Jasiński, M., Górska, A. (2018). Turystyka, eksport towarowy, pomoc rozwojowa i przekazy jako narzędzia przełamania stagnacji społeczno-gospodarczej w państwach Globalnego Południa o niekorzystnym położeniu geograficznym oraz najsłabiej rozwiniętych. Zeszyty Naukowe Szkoły Głównej Gospodarstwa Wiejskiego w Warszawie. Problemy Rolnictwa Swiatowego, 18(4), 199-208.

Jaszkiewicz, M., Latoszek, E. (2013). Polityka rozwojowa Unii Europejskiej. Geneza, ewolucja, zasady funkcjonowania. W: E. Latoszek, M. Proczek (red.). Polityka rozwojowa. Rola organizacji międzynarodowych w zwalczaniu ubóstwa na świecie. Warszawa: Oficyna Wydawnicza Szkoła Główna Handlowa w Warszawie. 
Jędrusik, M. (2003). Trzy modele kolonizacji turystycznej na przykładzie archipelagów mórz ciepłych. Przegląd Geograficzny, 1(75), 81-100.

Kachniewska, M., Niezgoda, A., Pawlicz, A. (2012). Globalizacja i internacjonalizacja działalności turystycznej. W: M. Kachniewska, E. Nawrocka, A. Niezgoda, A. Pawlicz (red.). Rynek turystyczny. Ekonomiczne zagadnienia turystyki. Warszawa: Oficyna Wolters Kluwer Business.

Landes, D.S. (2007). Bogactwo i nędza narodów. Dlaczego jedni są tak bogaci, a inni tak ubodzy. Warszawa: Warszawskie Wydawnictwo Literackie MUZA SA.

Leszczyński, A. (2016). Eksperymenty na biednych. Polityczny, moralny i ekonomicznych spór o to, jak pomagać skutecznie. Warszawa: Wydawnictwo Krytyki Politycznej.

McElroy, J.L. (2006). Small island tourist economies across the life cycle. Asia Pacific Viewpoint, 47(1), 61-77.

McElroy, J.L., Parry, C.E. (2010). The characteristics of small island tourist economics. Tourism and Hospitality, 10, 315-328.

Mirkowska-Ostatek, M. (2013). Oficjalna pomoc rozwojowa jako czynnik eliminujący skalę ubóstwa w państwach Trzeciego Świata. W: E. Latoszek, M. Proczek (red.). Polityka rozwojowa. Rola organizacji międzynarodowych $w$ zwalczaniu ubóstwa na świecie. Warszawa: Oficyna Wydawnicza Szkoła Główna Handlowa w Warszawie.

Moyo, D. (2009). Dead Aid. Why Aid Is Not Working and How There Is a Better Way for Africa. New York: Farrar, Straus and Giroux.

Piasecki, R. (2003). Rozwój gospodarczy a globalizacja. Ekonomia rozwoju w zderzeniu z rzeczywistością. Warszawa: Polskie Wydawnictwo Ekonomiczne.

Piasecki, R. (2007). Ewolucja teorii rozwoju gospodarczego krajów biednych. W: R. Piasecki (red.). Ekonomia rozwoju. Warszawa: Polskie Wydawnictwo Ekonomiczne.

Rodrik, D. (2002). Institutions, Integration, and Geography: In Search of the Deep Determinants of Economic Growth. Pozyskano z https://wcfia.harvard.edu/publications/institutions-integration-and-geography-search-deep-determinants-economic-growth

Rodrik, D., Subramanian, A. (2003). The Primacy of Institutions (and what this does and does not mean). Finance \& Development, 40(2), 31-34.

Sen, A. (2002). Rozwój i wolność. Poznań: Zysk i S-ka Wydawnictwo.

UNCTAD (1973). Proceedings of the United Nations Conference on Trade and Development Third Session. Santiago de Chile, 13 April to 21 May 1972. Volume I. Report and Annexes. New York: United Nations.

UNCTAD (2010). In-depth evaluation of UNCTAD's technical cooperation activities dedicated to least developed countries, landlocked developing countries, small island developing states and other structurally weak, vulnerable and small economies.

UNCTAD (2018). Pozyskano z https://unctad.org/

UNDP (2018). Human Development Indices and Indicators. 2018 Statistical Update.

Wodejko, S. (1989). Ruch przyjazdowy z zachodu do wybranych państw socjalistycznych jako wyraz luki na europejskim rynku turystycznym. Warszawa: Szkoła Główna Planowania i Statystyki.

Wodejko, S. (1998). Ekonomiczne zagadnienia turystyki. Warszawa: Wyższa Szkoła Handlu i Prawa.

Michał Jasiński, dr nauk ekonomicznych, Katedra Unii Europejskiej im. J. Monneta, Kolegium Ekonomiczno-Społeczne, Szkoła Główna Handlowa w Warszawie. Jego zainteresowania naukowe obejmują zagadnienia procesów rozwoju społeczno-gospodarczego państw Południa, w tym szczególnie w podgrupie małych rozwijających się gospodarek wyspiarskich (SIDS) oraz miejsca turystyki międzynarodowej i pomocy rozwojowej w tych procesach.

Michał Jasiński, $\mathrm{PhD}$ in Economics, Jean Monnet Chair of the European Union, Collegium of Socio-Economics, Warsaw School of Economics. His research interests include socio-economic processes of development in Global South especially in Small Island Developing States (SIDS) and International Tourism and Official Development Assistance (ODA) in those processes.

ORCID: 0000-0002-0546-5048

\section{Adres/address:}

Szkoła Główna Handlowa w Warszawie

Katedra Unii Europejskiej im. J. Monneta 
al. Niepodległości 162, 02-554 Warszawa, Polska

e-mail: michal.jasinski@sgh.waw.pl 